\title{
TANGGUNG JAWAB PERUSAHAAN DALAM PELAKSANAAN CSR (CORPORATE SOCIAL RESPONSIBILITY) KEPADA MASYARAKAT OLEH PT. PERKEBUNAN NUSANTARA I LANGSA DI GAMPONG ALUE DUA
}

\author{
Mulyana, Ramziati, Nasrianti \\ Fakultas Hukum Program Studi Hukum Unimal \\ Komplek Kampus Bukit Indah, Jl. Jawa - Blang Pulo Kecamatan Muara Satu \\ P.O.Box 141 Lhokseumawe Mobile 082331239196 Faks. (0645) 40209
}

\begin{abstract}
The implementation of corporate responsibility by PT. Perkebunan Nusantara I Langsa ithe form of partnership and community development programs by observing Law Number 40 year 2007 concerning Limited Liability Companies, Government Regulation Numer 47 year 2012 and strengthened by Ministerial Regulation Number PER-02/MBU/7/2017 concerning the Partnership and Community. Which cannot be denied that the positive impact on the community and environment, specifically in terms of granting capital loans as venture capital for fostered partners in Gampong Alue Dua. in the case of granting capital loasn, a legal relationship arises, namely rights and obligations between the company and the fostered partners considers that the venture capital fund is a grant from the campany.

The purpose of this study is to find out and explain the implementation of corporate responsibility to the community and the environment, and explain the implementation constraints and efforts to resolve the implementation of corporate responsibility.

This research in an empirical juridical legal research, with qualitative legal research types, the source of legal material used is primary and secondary legal materials, research collection techniques are carried ou by interview and literature study methods, research analysis is done by descriptive analysis.

Based on the results of research that PT. Perkebunan Nusantara I Langsa has implemented corporate social resposibilty in the from of the Partnership and Community Development Program. The constraints and resolution efforts faced by PT Perkebunan Nusantara I Langsa in the implementation of corporate social responsibility are divided into two, namely in the Partnership Program, the obstacles include: difficulty finding loan data, no confiscation seizure, wrong perception from the community, The Community Development Program has problems, namely difficulties in place surveys, The solution is a persuasive approach.

It is recommended to the company in the partnership program the need for a detailed explanation in the nechanism to be followed by the fostered partners from various stages so that the company has no difficulty in billing the fostered partners, and the company can balance petigas with the company's work area so that it is easy to conduct surveys or the didtribution of aid funds right on target.
\end{abstract}

Key words: Corporate Social Responsibility, PKBL, Implementation. 


\section{Jurnal Ilmiah Mahasiswa FAKULTAS HUKUM UNIMAL}

Tanggung Jawab.......(Mulyana, Ramziati, Nasrianti)

E-ISSN:

ISSN :

Volume 1 Nomor 1 Januari-April 2020 (halaman 59-73)

\begin{abstract}
Abstrak
Pelaksanaan tanggung jawab perusahaan oleh PT. Perkebunan Nusantara I Langsa dilaksanakan dalam bentuk Program Kemitraan dan Bina Lingkungan, sebagaimana diamanatkan oleh Undang-undang Nomor 40 Tahun 2007 tentang Perseroan Terbatas, Peraturan Pemerintah Nomor 47 Tahun 2012 dan dikuatkan dengan Peraturan Menteri BUMN Nomor PER-02/MBU/7/2017 tentang Program Kemitraan dan Bina Lingkungan, yang tidak dapat dipungkiri bahwa keberadaan PT.Perkebunan Nusantara I Langsa telah membawa dampak positif bagi masyarakat dan lingkungan hidup, khususnya dalam hal pemberian dana pinjaman pemodalan sebagai modal usaha untuk mitra binaan di Gampong Alue Dua. Dalam hal pemberian dana pinjaman pemodalan timbul hubungan hukum yaitu hak dan kewajiban antara pihak perusahaan dan mitra binaan, namun pada realitanya mitra binaan menganggap bahwa dana modal usaha tersebut merupakan hibah dari perusahaan.

Tujuan dalam penelitian ini untuk mengetahui dan menjelaskan pelaksanaan tanggung jawab perusahaan kepada masyarakat dan lingkungan hidup, dan menjelaskan kendala-kendala pelaksanaan serta upaya penyelesaian dalam pelaksanaan tanggung jawab perusahaan.

Penelitian ini adalah penelitian hukum yang bersifat yuridis empris, dengan jenis penelitian hukum kualitatif, sumber bahan hukum yang digunakan adalah bahan hukum primer dan bahan hukum sekunder, teknik pengumpulan data dilakukan dengan metode wawancara dan studi kepustakaan, analisis data dilakukan dengan cara deskriptif analisis.

Berdasarkan hasil penelitian bahwa PT. Perkebunan Nusantara I Langsa telah melaksanakan tanggung jawab perusahaan dengan bentuk Program Kemitraan dan Bina Lingkungan. Kendala-kendala dan upaya penyelesaian yang dihadapi oleh PT. Perkebunan Nusantara I Langsa dalam pelaksanaan Tanggung jawab sosial perusahaan dibagi menjadi dua, yaitu pada Program Kemitraan, kendalanya antara lain: kesulitan mencari data pinjaman, tidak diperolehkan sita anggunan, salah persepsi dari masyarakat. Program Bina Lingkungan kendalanya yaitu kesulitan dalam survei tempat. Upaya penyelesaiannya mengadakan pendekatan persuasif.

Disarankan kepada perusahaan pada program kemitraan perlunya penjelasan yang detail dalam mekanisme yang akan dilalui mitra binaan dari berbagai tahap sehingga perusahaan tidak kesulitan dalam melakukan penagihan pada mitra binaan, dan pada program bina lingkungan perusahaan dapat menyeimbangkan petugas dengan wilayah kerja perusahaan sehingga mudah dalam melakukan survei atau penyaluran dana bantuan tepat sasaran.
\end{abstract}

\title{
Kata Kunci: Tanggung Jawab Perusahaan, PKBL, Pelaksanaan
}

\section{PENDAHULUAN}

Dalam rangka mewujudkan masyarakat adil dan makmur berdasarkan Pancasila dan UUD RI 1945, maka perlu dilaksanakan pembangunan nasional yang berkelanjutan berlandaskan demokrasi ekonomi. Salah satu pendorong pembangunan nasional yaitu pelaksanaan usaha berbagai perusahaan. Perusahaan adalah keseluruhan perbuatan yang dilakukan secara tidak terputus-putus dengan terang-terangan dalam kedudukan tertentu dan untuk mencari laba bagi dirinya sendiri (Abdul Rasyid Salima, 2005). Perusahaan pada umumnya berdiri di tengahtengah masyarakat yang memasarkan hasil produksinya untuk memperoleh keuntungan, maka dari itu sebagai perusahaan yang baik harus peduli terhadap masyarakat dan lingkungan hidup. 
Jurnal Ilmiah Mahasiswa

FAKULTAS HUKUM UNIMAL

Tanggung Jawab.......(Mulyana, Ramziati, Nasrianti)

E-ISSN:

ISSN :

Volume 1 Nomor 1 Januari-April 2020 (halaman 59-73)

Pada prinsipnya sebuah perusahaan didirikan bertujuan untuk mendapatkan keuntungan secara maksimal dan mencegah kerugian atau menekan seminimal mungkin kerugian tetapi juga harus mementingkan kepentingan pihak lain. Menurut Busyra Azheri dalam jurnal Diana Tantri Cahyaningsih Djuwityastuti, bahwa "Perusahaan bukan lagi sebagai entitas yang hanya mementingkan diri sendiri atau egois (selfish) dengan lingkungan masyarakat, tetapi sebagai sebuah entitas badan hukum yang wajib melakukan adaptasi sosio kultural dengan lingkungan dimana ia berada, serta dapat dimintai pertanggung- jawaban layaknya subjek hukum pada umumnya".(Diana Tantri Cahyaningsih dan Djuwityastuti, 2015).

Dalam kamus hukum, tanggung jawab adalah keharusan bagi seseorang untuk melaksanakan apa yang telah diwajibkan kepadanya, tanggung jawab yang dimaksud adalah keadaan dimana subjek hukum wajib menanggung segala sesuatu, sehingga berkewajiban menanggung, memikul tanggung jawab dari akibat yang ditimbulkannya.(Sudarsono, 2012).

Tanggung jawab sosial perusahaan yang lebih dikenal dengan istilah Corporate Social Responsibility (selanjutnya disebut dengan CSR). CSR merupakan suatu komitmen perusahaan untuk membangun kualitas kehidupan yang lebih baik bersama dengan para pihak yang terkait, utamanya masyarakat di sekelilingnya dan lingkungan sosial dimana perusahaan tersebut berada, yang dilakukan terpandu dengan kegiatan usahanya secara berkelanjutan.(Arif Budimanta, Adi Prasetijo dan Bambang Rudito, 2008).

CSR berarti perusahaan harus memberikan dampak positif terhadap masyarakat dan lingkungan hidup. Selama ini perusahaan dianggap lembaga yang dapat memberikan banyak keuntungan bagi masyarakat, seperti memberikan kesempatan kerja, menyediakan barang yang dibutuhkan masyarakat untuk konsumsi, membayar pajak, memberi sumbangan, dan lain-lain. Namun dibalik itu semua keberadaan perusahaan ternyata juga banyak menimbulkan berbagai persoalan sosial dan lingkungan seperti polusi udara, keracunan, kebisingan, diskriminasi, pemaksaan, kesewenang-wenangan, produksi makanan haram serta bentuk pencemaran udara yang menganggu kesehatan dan lingkungan (negative externalities) (Nor Hadi, 2011).

Kewajiban pelaksanaan CSR yang telah menjadi tanggung jawab hukum perusahaan dari segi ekonomis dianggap tidak menguntungkan, tetapi jika dilakukan dengan benar, efektif, terstruktur, dan bersifat jangka panjang bukan hal yang mustahil jika kegiatan tersebut dapat memberi keuntungan ekonomis kepada perusahaan. Perusahaan dapat membentuk citra (image) perusahaan yang positif kepada stakehorder dan bagi kepentingan ekonomis perusahaan seperti untuk pemasaran produk dari perusahaan. Perusahaan pada dasarnya didirikan untuk mendapat keuntungan dan hal tersebut merupakan tanggung jawab ekonomi dari perusahaan, tetapi keuntungan tersebut juga harus diperoleh tanpa mengorbankan masyarakat dan lingkungan hidup.

Dalam Undang-undang Nomor 40 Tahun 2007 tentang Perseroan Terbatas (UUPT) yaitu pada Pasal 74 Ayat (1) menyatakan bahwa "Perseroan yang menjalankan kegiatan usahanya di bidang dan/atau berkaitan dengan sumber daya alam wajib melaksanakan Tanggung Jawab Sosial dan Lingkungan". Tujuan CSR yang diatur di dalam Pasal 1 Ayat 3 Undang-undang Nomor 40 Tahun 2007 tentang Perseroan Terbatas adalah untuk meningkatkan kualitas kehidupan dan lingkungan yang bermanfaat bagi perseroan itu sendiri, komunitas setempat dan masyarakat pada umumnya. Ketentuan ini bertujuan untuk tetap menciptakan hubungan 
Jurnal Ilmiah Mahasiswa

FAKULTAS HUKUM UNIMAL
Tanggung Jawab.......(Mulyana, Ramziati, Nasrianti)

E-ISSN:

ISSN :

Volume 1 Nomor 1 Januari-April 2020 (halaman 59-73) perseroan yang serasi, seimbang, dan sesuai dengan lingkungan, nilai, norma, dan budaya masyarakat setempat. Oleh karenanya, keberadaan perusahaan bukan bersifat menguasai terhadap lingkungan masyarakat melainkan memiliki ketergantungan yang membutuhkan lingkungan masyarakat. Perusahaan adalah pihak yang memanfaatkan sumber daya alam yang mana pemanfaatan tersebut berpotensi menimbulkan permasalahan (problem) sosial dan lingkungan, dan sebagai pihak yang memperoleh keuntungan dalam pemanfaatan sumberdaya tersebut, sementara masyarakat yang justru menanggung akibat negatif. Untuk itu, perusahaan harus bertanggung jawab atas berbagai dampak negatif terhadap lingkungan hidup. Perusahaan harus mengembalikan sebagian keuntungan yang diperoleh untuk kesejahteraan masyarakat dan untuk perbaikan kerusakan yang ditimbulkan terhadap lingkungan hidup.

Setiap perusahaan yang menjalankan usahanya terkait dengan lingkungan hidup wajib menjalankan CSR termasuk perusahaan Perseroan Terbatas Perkebunan Nusantara I Langsa selanjutnya disebut dengan (PT. Perkebunan Nusantara I Langsa). PT. Perkebunan Nusantara I Langsa merupakan perusahaan yang dimiliki oleh negara yang berorientasi dibidang perkebunan dan pengolahan kelapa sawit. PT. Perkebunan Nusantara I Langsa memiliki sembilan unit usaha yang mengelola budidaya kelapa sawit dan karet, yang menyebar di 6 (enam) Kabupaten yaitu Kabupaten Aceh Tamiang, Aceh Timur, Aceh Utara, Nagan Raya, Aceh Selatan dan Aceh Barat.

PT. Perkebunan Nusantara I Langsa diakui memberi sumbangsih dalam menggerakkan ekonomi nasional karena mempunyai (multiplier effect) yang sangat luas seperti menumbuhkan industri jasa terkait, kelestarian alam, penyediaan lapangan usaha, dan penyerapan tenaga kerja putra daerah. Berdasarkan data yang diperoleh dari media informasi seputar perusahaan PT. Perkebunan Nusantara I Langsa pelaksanaan CSR pada tahun 2018 perusahaan menyalurkan dana berupa Program Kemitraan dan Bina Lingkungan (selanjutnya disebut dengan PKBL) (Rusdi Hanafiah, 2018).

Program Kemitraan dan Bina Lingkungan adalah program peminjaman pemodalan usaha dan program bantuan (charity) terhadap masyarakat di Gampong Alue Dua Kecamatan Langsa Baro. Pada hakikatnya, PKBL adalah suatu jenis tanggung jawab sosial (Corporate Social Responsibility/CSR) yang hanya ada di Badan Usaha Milik Negara saja. CSR melalui PKBL terdiri dari dua jenis program yakni Program Kemitraan (PK) dan Bina Lingkungan (BL). Program Kemitraan (PK) adalah suatu program yang mewajibkan perusahaan PT. Perkebunan Nusantara I Langsa untuk memberikan pinjaman pemodalan usaha dan pembinaan kepada usaha mikro kecil dan menengah. Bina Lingkungan (BL) adalah suatu program yang diberikan melalui bantuan dana untuk keperluan program atau kegiatan pengembangan masyarakat yang meliputi seperti bantuan korban bencana alam, peningkatan kesehatan, pendidikan, sarana ibadah, sarana umum, pelestarian alam dan sosial masyarakat.

Dalam pelaksanaan CSR melalui PKBL fokus area kedua program tersebut adalah wilayah lokasi keberadaan PT. Perkebunan Nusantara I Langsa, dan pada tahun 2018 PKBL dilaksanaan di Gampong Alue Dua dan di beberapa wilayah lainnya yang merupakan tanggung jawab PT. Perkebunan Nusantara I Langsa untuk mewujudkan kemakmuran dan kesejahteraan bagi masyarakat dan lingkungan hidup yang lebih kreatif, mandiri dan berkomitmen.

Berdasarkan latar belakang di atas, maka penulis tertarik untuk mengkaji permasalahan mengenai "Pelaksanaan Tanggung Jawab Sosial Perusahaan (Corporate Social 
Respossibility/CSR) Kepada Masyarakat Oleh PT. Perkebunan Nusantara I Langsa Di Gampong Alue Dua".

\section{METODE PENELITIAN}

Jenis penelitian yang digunakan dalam penelitian ini adalah jenis penelitian kualitatif, yaitu penelitian yang menggunakan latar ilmiah, dengan maksud menafsirkan fenomena yang terjadi dan dilakukan dengan metode yang biasanya dimanfaatkan data wawancara dengan pendekatan yang dilakukan dalam penelitian ini adalah dengan menggunakan pendekatan yuridis empiris. Penelitian ini sering juga disebut penelitian lapangan, yang bertitik tolak pada data primer yang didapat melalui kegiatan wawancara.

\section{PEMBAHASAN}

Tanggung Jawab Perusahaan dalam pelaksanaan CSR (Corporate Social Responsibility) Kepada Masyarakat Oleh PT. Perkebunan Nusantara I Langsa Di Gampong Alue Dua

Menurut Undang-undang Nomor 40 Tahun 2007 tentang Perseroan Terbatas Pasal 1 Ayat (1) menyatakan:

"Perseroan Terbatas adalah badan hukum yang merupakan persekutuan modal, didirikan berdasarkan perjanjian, melakukan kegiatan usaha dengan modal dasar yang seluruhnya terbagi dalam saham dan memenuhi persyaratan yang ditetapkan dalam undang-undang ini dan peraturan pelaksanaannya".

Dari Pasal 1 Ayat (1) dapat diketahui bahwa Perseroan terbatas bahwa pengertian Perseroan terbatas adalah suatu badan hukum yang terdiri dari beberapa orang yang bernaung di bawah 1 (satu) nama bersama yang ditetapkan berdasarkan undang-undang. Perseroan terbatas berwenang untuk menerima, memegang dan mengalihkan harta kekayaan, menggugat atau digugat, dan melaksanakan kewenangan-kewenangan lainnya yang diberikan dan diberlakukan sebagai subjek hukum (personrecht) oleh pengadilan.

Menurut Achmad Ichsan Perseroan Terbatas nama aslinya adalah Naamloze Vennootschap/NV artinya tanpa nama yang maksudnya dalam hal pemberian nama perusahaan tidak memakai nama salah satu anggota persero melainkan menggunakan nama berdasarkan pada tujuan dari usahanya, dapat dijelaskan sebagai berikut (Rachmadi Usman, 2004):

"Perseroan Terbatas nama aslinya adalah Naamloze Vennootschap (NV) bagaimana asal mulanya sehingga disebut Perseroan Terbatas (PT), tidak dapat ditemukan. Naamloze Vennootschap sebenarnya berarti Perseroan Tanpa Nama yang berarti bahwa perseroan tersebut tidak memakai nama perseronya, namun diambil nama yang sesuai dengan tujuan dari perseroan tersebut, disebabkan perseroan terbatas mengeluarkan saham yang dapat diperjual belikan, sehingga kemungkinan saham persero yang namanya dipakai dalam perseroan terbatas tersebut tidak lagi menjadi miliknya".

Istilah Perseroan Terbatas sebagaimana yang telah diuraikan diatas bahwa perseroan pada mulanya tidak mempergunakan nama persero apabila tidak mempunyai maksud atau tujuan 
tertentu, dalam hal pemberian nama perseroan maka terlebih dahulu menentukan tujuan dari kegiatan usahanya.

Abdul kadir Muhammad menyatakan istilah "Perseroan" menunjuk kepada cara menentukan modal, yaitu bagian dalam saham, dan istilah "Terbatas" menunjuk kepada batas tanggung jawab pemegang saham, yaitu sebatas jumlah nominal saham yang dimiliki. Perseroan Terbatas adalah perusahaan persekutuan badan hukum yang mempunyai hak dan kewajiban layaknya sebagai manusia, yang mempunyai harta kekayaan sendiri yang terpisah dari sahamsaham perseroan. (Abdulkadir Muhammad, 2010).

Soedjono Dirjosisworo menyatakan PT adalah badan hukum yang didirikan berdasarkan perjanjian, melakukan kegiatan usaha dengan modal dasar yang seluruhnya terbagi dalam saham, dan memenuhi persyaratan yang ditetapkan dalam Undang-undang Nomor 40 Tahun 2007 tentang Perseroan Terbatas.

PT merupakan bentuk yang lazim dan banyak dipakai di Indonesia, karena PT yang menunjuk kepada cara menentukan modal dan merupakan badan hukum yang mandiri yang didirikan untuk menjalankan suatu perusahaan dengan modal perseroan tertentu yang terbagi atas saham-saham, dimana para pemegang saham (persero) ikut serta dengan mengambil satu saham atau lebih dan melakukan perbuatan-perbuatan hukum dibuat atas nama bersama, dengan tidak bertanggung jawab sendiri untuk persetujuan-persetujuan perseroan itu (dengan tanggung jawab yang semata-mata terbatas pada modal yang mereka setorkan) dengan maksud setiap anggota bergantung pada besar kecilnya jumlah saham yang dimiliki atau modal yang disetor, begitu juga besar kecilnya resiko yang harus ditanggung.

Dari pengertian PT terdapat beberapa unsur sebagai berikut: (M. Yahya Harahap)

1) Berbentuk badan hukum

PT adalah suatu badan hukum yang mempunyai hak dan kewajiban seperti layaknya seorang manusia, yang mempunyai harta kekayaan sendiri yang terpisah secara tegas dengan harta kekayaan pribadi para pemiliknya, dapat membuat perjanjian dengan pihak lain dan dapat bertindak sebagai pihak di depan Pengadilan.

2) Didirikan berdasarkan perjanjian

Perseroan Terbatas sebagai badan hukum didirikan atas dasar perjanjian, pendirian Perseroan Terbatas harus terdiri dari minimal dua orang atau pihak, karena pada hakikatnya tidak ada perjanjian jika hanya terdiri satu pihak saja.

3) Melakukan kegiatan usaha

Perseroan harus mempunyai maksud dan tujuan serta kegiatan usaha yang tidak bertentangan dengan ketentuan peraturan perundang-undangan, ketertiban umum, dan atau kesusilaan.

4) Modal terbagi atas saham

Perseroan Terbatas adalah suatu bentuk perseroan yang didirikan untuk menjalankan suatu perusahaan dengan modal perseroan tertentu yang terbagi atas saham-saham, dalam mana para pemegang saham ikut serta dengan mengambil satu saham atau lebih dan melakukan perbuatan-perbuatan hukum dibuat oleh nama bersama dengan tidak bertanggung jawab sendiri untuk persetujuan- persetujuan perseroan tersebut.

5) Lahirnya perseroan melalui proses hukum dalam bentuk pengesahan pemerintah 
Lahirnya perseroan sebagai badan hukum (rechts persoon, legal entity), karena diwujudkan melalui proses hukum (created by legal process) sesuai dengan ketentuan peraturan perundang-undangan yang berlaku.

\section{Bentuk-Bentuk Tanggung Jawab Perseroan Terbatas}

Tanggung jawab Perseroan Terbatas, secara hukum merupakan kewajiban bagi perusahaan. Atas dasar tersebut, maka Tanggung jawab perusahaan akan menjadi kewajiban yang harus dilaksanakan, baik demi terciptanya suatu kehidupan sosial yang baik maupun demi keberlangsungan dan keberhasilan kegiatan perusahaan itu sendiri. Pada hakikatnya Tanggung jawab perusahan adalah nilai atau jiwa yang melandasi aktivitas perusahaan secara umum, yang mencakup keseluruhan dari ruang lingkup dalam bidang ekonomi, hukum, dan sosial.

Menurut Post menyatakan tanggung jawab perusahaan terdiri dari tiga bentuk, yaitu bidang ekonomi (economic responsibility), bidang hukum (legal responsibility), dan bidang sosial (social responsibility), sebagai berikut:

1) Bidang Ekonomi (Economic Responsibility)

Keberadaan perusahaan ditunjukan untuk meningkatkan nilai bagi pemegang kepentingan (shakeholder), seperti meningkatkan keuntungan (laba), penciptaan lapangam kerja, produksi barang dan jasa yang bermanfaat bagi konsumen dan meningkatkan taraf hidup masyarakat.

2) Bidang Hukum (Legal Responsibility)

Sebagai bagian anggota masyarakat, PT memiliki tanggung jawab mematuhi peraturan perundangan yang berlaku. Karena perusahaan berkewajiban dan bertanggung jawab untuk menjaga ketertiban dan keteraturan tatanan sosial di lingkungan masyarakat. Dengan kata lain perusahaan adalah sebagai pengemban hak dan kewajiban layak subjek hukum.

3) Bidang Sosial (Social Responsibility)

Sebagaimana halnya dengan bidang-bidang lainnya Perseroan Terbatas pun mempunyai tanggung jawab di bidang sosial terhadap lingkungan dan para pemangku kepentingan (shakeholder), yang mencakup berbagai aspek seperti tanggung jawab untuk memajukan kegiatan pendidikan, peningkatan kesehatan, bantuan korban bencana alam, pelestarian alam dan sosial masyarakat.

Dengan demikian perusahaan dewasa ini memiliki berbagai aspek tanggung jawab. Perusahaan harus dapat mengelola tanggung jawab ekonominya kepada pemegang saham, memenuhi tanggung jawab hukum dengan mematuhi peraturan perundang-undangan yang berlaku, dan bertanggung jawab sosial kepada para stakeholder (pemegang kepentingan).

\section{Tanggung Jawab Sosial Perusahaan (Corporate Social Responsibility/CSR) Pengertian dan Dasar Hukum CSR}

Menurut Pasal 1 Ayat (3) Undang-undang Nomor 40 Tahun 2007 tentang Perseroan Terbatas menyatakan bahwa:

"Tanggung Jawab Sosial dan Lingkungan adalah komitmen Perseroan untuk berperan serta dalam pembangunan ekonomi berkelanjutan guna meningkatkan kualitas kehidupan dan 


\section{Jurnal Ilmiah Mahasiswa FAKULTAS HUKUM UNIMAL}

\section{E-ISSN:}

ISSN :

Volume 1 Nomor 1 Januari-April 2020 (halaman 59-73)

lingkungan yang bermanfaat, baik bagi Perseroan sendiri, komunitas setempat, maupun masyarakat pada umumnya".

CSR pada saat ini telah menjadi kewajiban bagi perusahaan, sebagaimana telah diatur dalam Undang-undang Nomor 40 Tahun 2007 tentang Perseroan Terbatas selanjutnya pada Pasal 74 yang berbunyi Ayat (1) menyatakan bahwa "Perseroan yang menjalankan kegiatan usahanya di bidang dan/atau berkaitan dengan sumber daya alam wajib melaksanakan Tanggung Jawab Sosial dan Lingkungan".

Dalam Peraturan Pemerintah Nomor 47 Tahun 2012 tentang Tanggung Jawab Sosial dan Lingkungan (TJSL) pada Pasal 3 Ayat (1) menyatakan bahwa " Tanggung jawab sosial dan lingkungan menjadi kewajiban bagi perseroan yang menjalankan kegiatan usahanya di bidang dan atau berkaitan dengan sumber daya alam berdasarkan Undang-undang.

Dari ketentuan di atas dapat dikatakan bahwa CSR merupakan kewajiban yang harus dilaksanakan perusahaan dalam pembangunan berkelanjutan guna meningkatkan kualitas kehidupan dan lingkungan yang bermanfaat baik bagi perusahaan sendiri, pemegang kepentingan (stakeholder) yang meliputi komunitas setempat, maupun masyarakat pada umumnya yang sesuai dengan Undang- undang Perseroan Terbatas dan ketentuan pelaksanaannya Peraturan Pemerintah.

Menurut Johnson menyatakan bahwa "CSR pada dasarnya berangkat dari filosofi bagaimana cara mengelolah perusahaan baik sebagian maupun secara keseluruhan memiliki dampak positif bagi dirinya dan lingkungan. Untuk itu, perusahaan harus mampu mengelolah bisnis operasinya dengan menghasilkan produk yang berientasi secara positif terhadap masyarakat dan lingkungan hidup. (Johnson dalam Nor hadi, 2011).

Ghana memberikan penjelasan secara lebih dalam, bahwa sesungguhnya tanggung jawab sosial perusahaan CRS memberikan kapasitas dalam membangun perusahaan (corporate building) menuju terjaminnya kelangsungan hidup (going concern) perusahaan. Didalamnya, termasuk upaya peka (respect) terhadap adopsi sistemik berbagai budaya (kearifan lokal) ke dalam strategi bisnis perusahaan termasuk keterampilan karyawan, masyarakat, dan pemerintah. Jonh Elklington menyatakan CSR ini lebih menekankan pada sejauh mana konsep suatu perusahaan untuk mengindahkan kewajibannya terhadap (stakeholders) yakni konsumen, karyawan, pemegang saham, masyarakat, dan lingkungan (ekologis) dalam semua aspek aktivitasnya, beliau juga menegaskan bahwa kewajiban dimaksud jauh lebih luas dari kewajiban menurut undang- undang yang ada. Dengan kata lain, kewajiban tersebut tidak hanya mencakup dalam arti yuridis formal. (Isa Wahyudi dan Busyra Azheri, 2011).

Dengan demikian, beberapa pengertian di atas dapat dikatakan bahwa CSR adalah suatu bentuk kewajiban yang telah diatur dalam Undang-undang kepada perusahaan untuk melaksanakan kewajiban yang berkelanjutan terhadap aspek ekonomi, sosial, dan lingkungan masyarakat sesuai dengan ketentuan hukum yang berlaku.

\section{Prinsip-Prinsip CSR}

Adapun yang perlu diperhatikan dalam pelaksanaan CSR, yaitu beberapa prinsip yang dapat dijadikan pedoman. David Crowther manyatakan bahwa ada 3 (tiga) prinsip pelaksanaan program CSR yakni keberlanjutan (sustainability), pertanggungjawaban (accountability), dan keterbukaan (transparency), secara ringkas dapat digolongkan sebagai berikut: (Nor Hadi, 2011).

a. Keberlanjutan (Sustainability)

Prinsip ini berkaitan dengan tindakan perusahaan yang dilakukan sekarang yang tetap memperhatikan dan memperhitungkan sumberdaya dimasa depan, terhadap dampak atau berpengaruh keputusan-keputusan dapat diambil untuk generasi masa depan. Prinsip 


\section{Jurnal Ilmiah Mahasiswa FAKULTAS HUKUM UNIMAL}

\section{E-ISSN:}

ISSN :

Volume 1 Nomor 1 Januari-April 2020 (halaman 59-73) keberlanjutan juga memberikan arahan bagaimana penggunaan sumberdaya dalam melakukan kegiatan yang berkelanjutan untuk masa yang akan datang. Adapun 7 prinsip keberlanjutan meliputi, pertumbuhan yang berkelanjutan, merubah kualitas pertumbuhan ekonimi, pemenuhan kebutuhan seperti tenaga kerja, makanan, energi, dan air, pemeliharaan dan peningkatan basis sumberdaya, orientasi teknologi terus menerus dan mampu mengatur resiko, menggabungkan lingkungan dan ekonomi dalam pengambilan keputusan.

b. Pertanggungjawaban (Accountability)

Dalam sebuah organisasi mengenali setiap aktivitas yang langsung maupun tidak langsung yang berdampak pada lingkungan luar atau diartikan sebagai bertanggung jawab atas tindakan yang dilakukan. Prinsip ini berlaku dengan memperhatikan dan memperhitungkan akibat apa saja yang dapat timbul dari tindakan yang diambil baik dalam (internal) perusahaan maupun luar (external). Lebih kepada pelaporan terhadap stakeholder yang berhubungan dan menjelaskan bagaimana keterkaitannya antara aktifitas yang dilakukan terhadap stakeholder.

c. Keterbukaan (Transparency)

Merupakan sebuah prinsip dimana sebuah dampak eksternal dilaporkan secara nyata tanpa disembunyikan. Keterbukaan merupakan prinsip yang berkaitan dengan kedua prinsip CSR dan dapat dikatakan sama dengan proses pengenalan tanggung jawab terhadap efek yang dapat ditimbulkan oleh pihak perusahaan terhadap stakeholder. Stakeholder dengan sadar dapat menjalankan dirinya sebagai fungsi pengawasan kepada perusahaan, karena pada dasarnya perusahaan memiliki prinsip keterbukaan dalam setiap kegiatan yang usahanya. Pelaksanaan CSR tanpa inovasi dan kolaborasi perusahan dengan stakeholder akan menghasilkan program "basa-basi", sedangkan program CSR yang efektif dan terbukai akan memunculkan sebuah inovasi yang dapat diartikan sebagai sebuah komitmen perusahaan dengan memperhatikan kepentingan stakeholder.

Pelaksanaan CSR sudah diyakini sebagai suatu kewajiban oleh perusahaan, perusahaan harus berusaha semaksimal mungkin menekan pada prinsip-prinsip keberlanjutan, pertanggungjawaban dan keterbukaan. Artinya perusahaan membuat program CSR yang dapat dilakukan secara bersinambungan, bukan sekedar membagi-bagi uang dalam jangka waktu yang singkat. Program CSR perlu direncanakan dilakukan dengan pemantauan (monitoring) serta penilaian (evaluation) untuk jangka waktu yang berkelanjutan.

\section{Tujuan CSR}

Pelaksanaan CSR yang didasarkan pada banyak tujuan dan sekurang- kurangnya terdapat tiga alasan penting mengapa perusahaan harus merespon dan melaksanakan CSR agar sejalan dengan jaminan berkelanjutan operasional perusahaan. Sebagaimana dikemukakan oleh Wibisono sebagai berikut (Rahmatullah dan Trianita Kurniati, 2011):

a. Perusahaan adalah bagian dari masyarakat dan oleh karenanya wajar bila perusahaan memperhatikan kepentingan masyarakat dan lingkungan. Perusahaan mesti menyadari bahwa mereka beroperasi dalam satu tatanan lingkungan masyarakat. Tujuan pelaksanaan tanggung jawab oleh perusahaan berfungsi sebagai kompensasi atau upaya timbal balik atas penguasaan sumber daya alam atau sumber daya ekonomi oleh perusahaan yang kadang bersifat ekspansif dan eksploratif disamping sebagai kompensasi sosial karena timbul ketidak nyamanan (discomfort) pada masyarakat.

b. Perusahaan dan masyarakat sebaiknya memiliki hubungan yang bersifat simbiosis mutualisme (saling menguntungkan) untuk mendapatkan dukungan dari masyarakat. Wajar bila perusahaan dituntut untuk memberikan kontribusi positif kepada masyarakat sehingga bisa tercipta harmonisasi hubungan bahkan pendongkrakan citra dan performa perusahaan.

c. Pelaksanaan CSR merupakan salah satu cara untuk meredam atau bahkan 


\section{Jurnal Ilmiah Mahasiswa FAKULTAS HUKUM UNIMAL}

\section{E-ISSN:}

ISSN :

Volume 1 Nomor 1 Januari-April 2020 (halaman 59-73) menghindarkan konflik sosial. Potensi konflik itu bisa berasal akibat dari dampak operasional perusahaan atau akibat kesenjangan struktur dan ekonomi yang timbul antara masyarakat dengan komponen perusahaan.

Dari uraian di atas dapat dikatakan meskipun secara moral perusahaan mengejar keuntungan, bukan berarti perusahaan dibenarkan mencapai keuntungan tersebut dengan mengorbankan kepentingan-kepentingan pihak lain yang terkait. Oleh karenanya, setiap perusahaan harus bertanggung jawab atas tindakan atau kegiatan dari usahanya yang akan menimbulkan dampak negatif baik secara langsung maupun tidak langsung terhadap lingkungan sosial dimana perusahaan melakukan aktivitas usahanya serta tidak bertentangan dengan aturan hukum di Indonesia.

\section{Manfaat CSR}

Dalam menjalankan CSR, perusahaan memfokuskan perhatian pada tiga hal, yaitu keuntungan (laba), masyarakat, dan pemerintah. Dengan memperoleh laba, perusahaan dapat memberikan sebagian laba yang diperoleh guna membiayai pertumbuhan dan pengembangan usaha di masa depan, serta membayar pajak kepada pemerintah. Perhatian kepada masyarakat dapat dilakukan dengan cara melakukan kegiatan-kegiatan serta pembuatan kebijakan-kebijakan yang dapat meningkatkan kesejahteraan masyarakat di berbagai bidang. Manfaat yang diberikan oleh perusahaan diharapkan akan mampu dimanfaatkan untuk meningkatkan kualitas hidup masyarakat.

Nor Hadi menyatakan bahwa dengan adanya hubungan simbolis mutualisme (hubungan yang saling menguntungkan) antara perusahaan dengan masyarakat dan pemerintah, eksistensi perusahaan diharapkan memiliki kemanfaatan tidak hanya untuk perusahaan saja, melainkan juga bagi masyarakat, dan pemeritah, sebagai berikut (Nor Hadi, 2011):

\section{a. Manfaat CSR Bagi Perusahaan}

Keberadaan perusahaan dapat tumbuh dan berkelanjutan, selain itu perusahaan juga mendapatkan citra (image) yang positif dari masyarakat luas, lebih mudah memperoleh akses terhadap kapital (modal), selanjutnya perusahaan dapat meningkatkan pengambilan keputusan pada hal-hal yang kritis (critical decision making) dan mempermudah pengelolaan menajemen risiko (risk management), perusahaan juga dapat mempertahankan sumber daya manusia (human resource) yang berkualitas. (Isa Wahyudi dan Busyra Azheri,2011)

b. Manfaat CSR Bagi Masyarakat

Dengan memperhatikan masyarakat, perusahaan dapat berkontribusi terhadap peningkatan kualits hidup masyarakat. Perhatian terhadap masyarakat dapat dilakukan dengan cara perusahaan melakukan aktivitas-aktivitas serta pembuatan kebijakan-kebijakan yang dapat meningkatkan kesejahteraan masyarakat, kualitas hidup, dan kompetensi masyarakat di berbagai bidang. Dengan memperhatikan lingkungan, perusahaan dapat ikut berpartisipasi dalam usaha pelestarian lingkungan demi terpeliharanya kualitas hidup masyarakat dalam jangka panjang.

c. Manfaat CSR Bagi Pemerintah

Pelaksanaan CSR juga memberikan manfaat bagi pemerintah, melalui CSR akan tercipta hubungan antara pemerintah dan perusahaan dalam mengatasi berbagai masalah sosial, seperti kemiskinan, rendahnya kualitas pendidikan, minimnya akses kesehatan, dan lain sebagainya. Dengan kehadiran CSR cukup banyak memberikan kontribusi kepada pemerintah. Dengan demikian, dari sisi perusahaan terdapat berbagai manfaat yang dapat diperoleh dari adanya CSR yang meliputi mengurangi resiko dan tuduhan terhadap perilaku yang tidak pantas yang diterima perusahaan, memiliki image dan mampu memperbaiki serta mempererat hubungan dengan stakeholder dan perusahaan mampu meningkatkan penjualan produk yang 


\section{Jurnal Ilmiah Mahasiswa FAKULTAS HUKUM UNIMAL}

E-ISSN:

ISSN :

Volume 1 Nomor 1 Januari-April 2020 (halaman 59-73)

dihasilkan.

Selanjutnya dengan melakukan kegiatan CSR masyarakat yang juga sebagai konsumen perusahaan akan lebih mengenal perusahaan dan dapat menciptakan image baik pada produk perusahaan akan lebih dikenal oleh masyarakat dan menimbulkan kesadaran akan keberadaan produk yang akan meningkatkan penjualan. Tidak hanya kepada masyarakat saja, perusahaan juga melakukan relasi kepada pemangku kepentingan lainnya yakni pemerintah melalui pembayaran pajak yang wajar oleh perusahaan. Dengan demikian, perusahan dapat mewujudkan visi misinya melalui kegiatan CSR yang dilakukannya serta mampu menonjolkan keunggulannya dimata stakeholder yang dapat membedakan dengan perusahaan lainnya.

\section{Jenis-jenis CSR}

Di kalangan sebagian dunia usaha, sudah tumbuh pengakuan bahwa keberhasilan ekonomi dan finansial mereka berkaitan erat dengan kondisi sosial dan lingkungan dimana perusahaan melakukan kegiatan usahanya. Untuk mewujudkan tanggung jawabnya perusahaan diharapkan memperhatikan dengan sungguh-sungguh pelaksanaan CSR dalam aktivitas usahanya. Oleh karenanya ada beberapa jenis CSR yang dapat dilaksanakan oleh perusahaan dianatarnya sebagai berikut (Mukti Fajar, 2013):

1. CSR Pendidikan

Sebagai salah satu pilar pembangunan bangsa, pendidikan tidak dapat diabaikan oleh perusahaan dalam menerapkan CSR. maka tidak mengherankan pendidikan adalah bidang yang tidak terlewatkan pelaksanaan CSR oleh setiap Perusahaan.

2. CSR Kesehatan

Peningkatan kesehatan suatu penduduk adalah salah satu target perusahaan. Dengan demikian, program-program CSR sudah sebaiknya tidak meninggalkan programnya dibidang kesehatan bisa dilakukan dengan cara, disesuaikan dengan kebutuhan dan apa yang semestinya dilakukan di daerah setempat.

3. CSR Ekonomi

Peningkatan taraf hidup masyarakat dalam bidang ekonomi menjadi perhatian penting bagi setiap perusahaan dalam kebijakan CSR nya. Peningkatan pendapatan ekonomi bisa diterapkan dengan mengembangkan Lembaga Keuangan mikro, bantuan modal kepada pengusah-pengusaha kecil, dan pemberdayaan petani.

4. CSR Lingkungan

Lingkungan yang baik adalah harapan setiap pihak. Belakangan ini dunia sangat disibukkan dengan masalah global warming yang mengancam kehidupan manusia. Dalam masalah ini salah satu pihak yang disalahkan adalah perusahaan. Aktifitas industri perusahaan dituding sebagai penyebab utama terjadinya global warming. Tanggung jawab perusahaan terhadap lingkungan ini dapat dijaga oleh perusahaan antara lain dengan cara menggunakan teknologi yang ramah lingkungan demi mengurangi emisi gas buang, mengimplementasikan sistem manajemen resiko yang efektif dan lain sebagainya. Dari penjelasan di atas semua jenis CSR tersebut, perusahaan harus melaksanakan kewajibannya bukan semata-mata untuk mendapatkan keuntungan ataupun untuk keberlansungan usahanya akan tetapi bertanggung jawab atas keseluruhan tindakan yang dilakukan sekarang yang dikemudian hari akan berdampak atau mempengaruhi terhadap keputusan-keputusan yang akan diambil untuk generasi di masa mendatang.

\section{Bentuk-Bentuk Program CSR}

CSR yang berkembang di kalangan dunia usaha dewasa ini bukanlah murni atas dasar kesadaran perusahaan, tetapi merupakan kewajiban dalam menghadapi tuntutan peraturan 


\section{Jurnal Ilmiah Mahasiswa FAKULTAS HUKUM UNIMAL}

\section{E-ISSN:}

ISSN :

Volume 1 Nomor 1 Januari-April 2020 (halaman 59-73) hukum yang berlaku. Tuntutan ini diatur juga sesuai dengan ketentuan dunia internasional seperti ISO 26000 International Orgamization for Standardization, (panduan tanggung jawab sosial) adalah suatu standar yang memuat panduan perilaku bertanggung jawab sosial bagi perusahaan guna berkontribusi terhadap pembangunan berkelanjutan. (Isa Wahyudi Dan Busyra Azheri, 2011).

ISO 26000 tentang bentuk-bentuk program CSR, ditetapkan adanya 7 (tujuh) bentuk sebagai perilaku perusahaan yang didasarkan atas standar dan panduan berperilaku dalam konteks situasi tertentu, sebagai berikut (Sabela, 2015):

1. Tata kelola organisasi (organizational governance), sistem pengambilan dan penerapan keputusan perusahaan dalam rangka pencapaian tujuannya.

2. Hak asasi manusia (human rights), hak dasar yang berhak dimiliki semua orang sebagai manusia, yang antara lain mencakup hak sipil, politik, ekonomi, sosial, dan budaya.

3. Praktik ketenagakerjaan (labour practices), segala kebijakan dan praktik yang terkait dengan pekerjaan yang dilakukan di dalam atau atas nama perusahaan.

4. Lingkungan (the environment), dampak keputusan dan kegiatan perusahaan terhadap lingkungan.

5. Prosedur operasi yang wajar (fair operating procedures), perilaku etis organisasi saat berhubungan dengan organisasi dan individu lain.

6. Isu konsumen (consumer issues), tanggung jawab perusahaan penyedia barang atau jasa terhadap konsumen dan pelanggannya.

7. Pelibatan dan pengembangan masyarakat (community involvement and development), hubungan organisasi dengan masyarakat di sekitar wilayah operasinya.

ISO 26000 sebagai pedoman aktivitas CSR bagi perusahaan-perusahaan untuk menjalankan bentuk-bentuk dari program CSR yang telah ditetapkan dalam ketentuan internasional. Dengan demikian, ISO 26000 juga memberikan pedoman tambahan kepada perusahaan untuk menjalankan bentuk program CSR dengan cara mengembangkan tata kelola perusahaan, menghormati hak asasi manusia, menghasikan produk dari usahanya yang wajar, bekerja sama dengan masyarakat disekitar perusahaan dalam pengembangan dan pelestarian lingkungan.

Di Indonesia, CSR dinyatakan dengan tegas dalam Undang-undang Nomor 40 Tahun 2007 tentang Perseroan Terbatas, disebutkan bahwa Perseroan Terbatas yang menjalankan usaha di bidang dan/atau bersangkutan dengan sumber daya alam wajib menjalankan tanggung jawab sosial dan lingkungan (Pasal 74 Ayat 1). Pada Ayat 2 ditegaskan kembali bahwa pelaksanaan CSR merupakan kewajiban Perseroan Terbatas, pada Ayat, 3 dan 4 disebutkan bahwa CSR "dianggarkan dan diperhitungkan sebagai biaya perseroan yang pelaksanaannya dilakukan dengan memperhatikan kepatutan dan kewajaran". Perseroan Terbatas yang tidak melakukan CSR dikenakan sanksi sesuai dengan peraturan dan perundang- undangan. Ketentuan lebih lanjut mengenai CSR diatur dalam Peraturan Pemerintah Nomor 47 Tahun 2012 tentang Tangung Jawab Sosial dan Lingkungan Perseroan Terbatas (Arif Budimanta, Adi Prasetijo dan Bambang Rudito, 2008).

Jika dicermati, peraturan tentang CSR yang relatif lebih terperinci adalah Peraturan Menteri Badan Usaha Milik Negara Nomor PER-02/MBU/7/2017, yang mengatur mulai dari besaran dana hingga tata cara pelaksanaan CSR. CSR milik BUMN adalah Program Kemitraan dan Bina Lingkungan (PKBL). Dalam Undang-Undang BUMN dinyatakan bahwa selain mencari keuntungan, peran BUMN adalah juga memberikan bimbingan bantuan secara aktif 


\section{Jurnal Ilmiah Mahasiswa FAKULTAS HUKUM UNIMAL}

Tanggung Jawab.......(Mulyana, Ramziati, Nasrianti)

E-ISSN:

ISSN :

Volume 1 Nomor 1 Januari-April 2020 (halaman 59-73)

kepada pengusaha golongan lemah, koperasi dan masyarakat. Selanjutnya, Peraturan Menteri BUMN menjelaskan bahwa sumber dana PKBL berasal dari penyisihan laba bersih perusahaan sebesar $2 \%$ persen yang dapat digunakan untuk Program Kemitraan ataupun Bina Lingkungan. Program kemitraan diberikan dalam bentuk pinjaman untuk membiayai modal usaha dalam rangka meningkatkan produksi dan penjualan. Sasaran program kemitraan adalah usaha kecil yang berada di sekitar perusahaan. Sedangkan Program bina lingkungan adalah program yang dilakukan untuk memberikan manfaat kepada masyarakat di sekitar perusahaan, diwujudkan dalam bentuk bantuan korban bencana alam, bantuan pendidikan atau pelatihan, bantuan peningkatan kesehatan, bantuan pengembangan sarana prasarana umum dan bantuan tempattempat ibadah. Melalui Progam Kemitraan dan Bina Lingkungan diharapkan dapat meningkatkan potensi dan kondisi ekonomi masyarakat, dengan fokus diarahkan pada pengembangan ekonomi masyarakat dan pemerataan pembangunan berkelanjutan.

\section{Kesimpulan}

Berdasarkan uraian yang telah dipaparkan oleh penulis sebelumnya dapat ditarik kesimpulan bahwa pelaksanaan (PKBL) dilakukan dengan 2 (dua) kegiatan utama, yaitu: Program Kemitraan. Kegiatan ini berupa pemberian pinjaman untuk membiayai modal kerja dan/atau pembelian aset tetap dalam rangka meningkatkan produksi dan penjualan mitra binaan. Program Kemitraan di Gampong Alue Dua diantaranya: bantuan sektor perdagangan, bantuan dan bantuan sektor industri. Dan pada Bina Lingkungan adalah program pemberdayaan kondisi sosial masyarakat oleh perusahaan. Bantuan program Bina Lingkungan diantaranya: bantuan pendidikan dan bantuan sarana ibadah. Kendala-kendala dan upaya penyelesaian terkait pelaksanaan CSR melalui Program Kemitraan dan Bina Lingkungan oleh PT. Perkebunan Nusantara I Langsa. Kendala-kendala terkait pelaksanaan pada program kemitraan yaitu persepsi masyarakat yang menganggap bahwa dana program kemitraan merupakan hibah dari perusahaan. dan pada Bina Lingkungan, wilayah bantuan yang sulit dijangkau menyebabkan proses evaluasi tidak maksimal dan terhambat di Gampong Alue Dua. Upaya penyelesaian terkait pelaksanaan pada program kemitraan yaitu mengadakan pendekatan persuasif serta memberi solusi kepada mitra binaan sehingga mampu melunasi angsuran pinjaman modalnya. Dan pada Bina Lingkungan yaitu mengadakan survei tempat yang lebih selektif sehingga dana bantuan yang disalurkan tepat sasaran.

\section{Saran}

Berdasarkan pada hasil penelitian dan analisis, maka studi ini menyarankan hal-hal sebagai berikut: Perlu adanya optimalisasi pelaksanaan program oleh PT. Perkebunan Nusantara I Langsa dalam melakukan penyaluran, pemantauan dan pembinaan kepada mitra binaan, agar tujuan untuk menciptakan usaha yang tangguh dan mandiri serta pemberdayaan kondisi sosial masyarakat dapat tercapai dengan baik dari waktu ke waktu. Selain itu, Perlunya penjelasan yang detail dalam mekanisme yang akan dilalui mitra binaan dari berbagai tahap sehingga petugas tidak kesulitan dan tahap melakukan penagihan pada mitra binaan.

Bagi pengelola PKBL PT. Perkebunan Nusantara I Langsa, perlu adanya penyediaan petugas pengelola PKBL yang seimbang sehingga mudah dalam melakukan survei atau penyaluran dana bantuan tepat sasaran pada program Bina Lingkungan. 
DAFTAR PUSTAKA

Arif Budimanta, Adi Prasetijo, Bambang Rudito, 2008, Corporate Social Responsibility Alternatif Bagi Pembangunan Indonesia, Indonesia Center For Sustainable Development, Jakarta.

Abdul Rasyid Saliman, 2005, Hukum Bisnis Untuk Perusahaan, Teori Dan Contoh Kasus, Frenada Media, Jakarta.

Abdulkadir Muhammad, 2010, Hukum Perusahaan Indonesia, PT Citra Aditya Bakti, Bandung.

Burhan Bungin 2006, Metode Penelitian Kualitatif, PT. Raja Grafindo Persada, Jakarta.

Chalid Narbuko dan Abu Ahmad, 2007, Metode Penelitian, Bumi Aksa, Jakarta. Fakultas Hukum Universitas Malikussaleh, 2016, Panduan Penulisan Tuga Akhir Skripsi, Lhokseumawe.

Diana Tantri Cahyaningsih Dan Djuwityastuti, Pelaksanaan Tanggung Jawab Sosial Perusahaan (CSR) PT. Pelabuhan Indonesia Iii Perser, Jurnal Hukum, Fakultas Hukum, Diakses Pada Tanggal 11 Desember 2018, Pukul14.34 Wib.

Fakultas Hukum Universitas Malikussaleh, 2013-2014, Program Studi Ilmu Hukum S1 Pedoman Pembelajaran, Lhokseumawe.

Hadi Nor, 2011, Corporate Social Responsibility, Graha Ilmu, Yogjakarta. Hilman Hadikusuma, 1995, Metode Pembuatan Kertas Kerja Atau Skripsi IlmuHukum, Mandar Maju, Bandung.

Isa Wahyudi dan Busyra Azheri, 2011, Corporate Social Responsibility Prinsip, Pengaturan dan Implementasi, Katalog Dalam Terbitan, Malang.

J. Supranto, 2003, Metode Penelitian Hukum Dan Statistik, PT Rineka Cipta, Jakarta.

M. Yahya Harahap, Hukum Perseroan Terbatas, Sirna Grafika, Jakarta.

Meilanny Budiarti dan Santoso Tri Raharjo, Corporate Social Resposibility Dari Sudut Pandang Perusahaan, Jurnal, Diakses Pada Tanggal 7 November 2018, Pukul 08:21 Wib.

Mukti Fajar dan Yulianto Achmad, 2010, Dualisme Penelitian Hukum Normatif Dan Empiris, Pustaka Pelajar, Yogyakarta.

Peraturan Pemerintah Nomor 47 Tahun 2012 tentang Tanggung Jawab Sosial dan Lingkungan.

Peraturan Menteri Badan Usaha Milik Negara Nomor PER-02/MBU/7/2017.

Rahmatullah dan Trianita Kurniati, 2011, Panduan Praktis Pengelolaan CSR,Samudra Biru, Yogjakarta. 
Republik Indonesia, Undang-Undang Tentang Perseroan terbatas, Undang- Undang Nomor 40 Tahun 2007.

Rachmadi Usman, 2004, Dimensi Hukum Perusahaan Perseroan Terbatas P.T Alumni, Bandung

Rusdi Hanafiah, PTPN I Langsa Salurkan Dana Corporate Social Responsibity www:// globa aceh.com/, Diakses pada 16 November 2018.

Sudarsono, 2012, Kamus Hukum, Rineka Cipta, Jakarta.

Silalahi Ulber, 2009, Metodologi Penelitian Sosial, PT Refika Aditama, Bandung. Sugiyono, 2014, Metode Penelitian Kualitatif, CV Alfabeta. Bandung.

Zainuddin Ali, 2009, Metode Penelitian Hukum, Sinar Grafika, Jakarta. 